\title{
A "vergonha" como uma "ofensa": homossexualidade feminina, família e micropolíticas da emoção
}

Shame as an offense: female homosexuality, family and micropolitics of emotion

\author{
Leandro de Oliveira* \\ *Universidade Federal de Minas Gerais - Belo Horizonte, MG, Brasil \\ leandroclam@yahoo.com.br \\ https://orcid.org/0000-0002-2793-0959
}




\title{
Resumo
}

O artigo discute o tema da revelação da orientação homossexual para a família de origem sob a perspectiva da antropologia das emoções, a partir da experiência de uma jovem lésbica de camadas médias. O depoimento tematiza tensões vivenciadas na esfera doméstica após a revelação da orientação sexual para os pais, com destaque para uma situação específica, na qual a mãe teria expressado "vergonha" pelo fato de ter uma filha "lésbica". A "vergonha" da mãe é considerada insultante pela filha, pois recusa uma forma de consideração almejada. A análise evidencia como discursos emocionais podem operar micropoliticamente, não apenas na demarcação e reforço de hierarquias, mas também em sua contestação.

Palavras-chave: emoção; homossexualidade; gênero; família.

\begin{abstract}
The article discusses the revelation of the homosexual orientation to the family of origin from the perspective of the anthropology of the emotions, based on the experience of a young middle-class lesbian. The testimony thematizes tensions experienced in the domestic sphere after the disclosure of sexual orientation to her parents, highlighting a specific situation in which the mother would have expressed "shame" for having a lesbian daughter. The mother's shame is considered insulting by her daughter, since it refuses a desired form of consideration. The analysis highlights how emotional discourses can operate micropolitically, not only defining and reinforcing, but also questioning hierarchies.
\end{abstract}

Keywords: emotion; homosexuality; gender; family. 
Este artigo aborda o tema da revelação da orientação homossexual para a família sob a perspectiva da antropologia das emoções. A reflexão apresentada integra projeto mais abrangente, conduzida na região metropolitana do Rio de Janeiro entre os anos de 2007 e 2011, que investigou situações vivenciadas por gays e lésbicas na relação com suas famílias de origem contextualizadas contra o cenário contemporâneo de luta política e reivindicações por reconhecimento entre minorias sexuais e que resultou em minha tese de doutorado (Oliveira, L., 2013). Essa pesquisa mais abrangente se baseou em análise documental, etnografia e em entrevistas em profundidade inspiradas nas técnicas de "história de vida" (Becker, 1999; Debert, 1986; Queiroz, 1991) e "história de família" (Barros, 1987; Cabral; Lima, 2005; Duarte; Gomes, 2008). Os depoimentos analisados na tese foram coletados com dez interlocutores pertencentes a segmentos de camadas médias e a segmentos ascendentes de camadas populares - oito jovens com idades entre 20 e 30 anos (sete homens gays e uma mulher lésbica), além de duas mulheres (uma heterossexual e uma lésbica) na casa dos 40 anos que tinham filhos homo/bissexuais. As narrativas fornecidas por esses interlocutores foram tomadas como casos privilegiados para a visibilização de certas experiências e de discursos emocionais que compareciam entrelaçados a processos de reelaboração do self e dos vínculos familiares, com especial atenção às experiências de manutenção do segredo, às situações envolvidas na visibilização da orientação sexual e às narrativas sobre maior ou menor "aceitação" da homossexualidade. O trabalho consistiu em experimento etnográfico no qual as narrativas sobre si, sobre a própria sexualidade, sobre a própria família e sobre situações vivenciadas com familiares e parceiros amorosos foram tomadas como indícios interconectáveis que apontam para processos sociais e formas de falar sobre a experiência social - aproximável à estratégia de "seguir as biografias", identificada por Marcus (1995) como uma das formas possíveis de multi-sited ethnography.

Neste artigo, discuto experiências relatadas por uma jovem branca, lésbica e pertencente a camadas médias, moradora da Zona Norte da cidade do Rio de Janeiro. O depoimento tematiza tensões vivenciadas pela entrevistada após a revelação de sua orientação sexual para seus pais. Analiso o modo como essa entrevistada aciona discursos emocionais na percepção e interpretação de reações de seus familiares à visibilização de sua orientação sexual, com especial atenção à noção de vergonha. Esse caso foi escolhido por colocar em evidência 
o potencial micropolítico desses discursos emocionais, que podem comparecer na reiteração, mas também no questionamento/reinvenção de convenções tocantes a sexualidade, gênero e família.

Desde fins do século XX, estudos no campo da antropologia das emoções têm problematizado a noção de que as "emoções" seriam fenômenos "naturais", "espontâneos" e/ou "individuais", salientando seu caráter de construção coletiva (Lutz; White, 1986). Aquilo que nomeamos como "emoções" pode ser tomado como uma forma de linguagem ou discurso, e como um modo de conexão entre as pessoas no mundo que se articula a aspectos da estrutura social. Devido a essa capacidade de dramatizar relações sociais, o discurso sobre as emoções, a expressão de emoções e o discurso emotivo são dotados de um potencial micropolítico para a legitimação ou contestação de hierarquias (Abu-Lughod; Lutz, 1990; Coelho, 2010; Rezende; Coelho, 2010). Discursos emocionais podem, desse modo, desempenhar um trabalho de inclusão ou exclusão social, afirmando o pertencimento ou não de uma pessoa a um dado grupo, e reiterando ou desestabilizando convenções culturais e formas de ordenamento social.

A antropologia das emoções, campo de debates que emerge nos Estados Unidos entre fins dos anos 1970 e início dos anos 1980, é debitária de discussões conduzidas no âmbito dos estudos de gênero e pensamento feminista (Despret, 2011; Lutz, 1988). Ao problematizar definições convencionais da oposição natureza/cultura, os estudos de gênero abriram espaço para reconhecimento e crítica das conexões metonímicas entre feminilidade, natureza e emoção (assim como para a crítica do dualismo razão/emoção, que define as emoções como domínio desqualificado por oposição à razão, considerada atributo masculino, e que ocupa lugar central na etnopsicologia ocidental moderna). A antropologia das emoções se amparou também em releituras do pensamento de Michel Foucault, notadamente as reflexões sobre a relação entre discurso, subjetividade e poder que marcaram as análises de Foucault sobre a sexualidade (Abu-Lughod; Lutz, 1990). Se o feminismo evidenciou que nossas concepções acerca daquilo que é ou não "natural" estão atravessadas por relações de poder, a analítica de inspiração foucaultiana ajudou a complexificar essa concepção de poder, colocando em evidência como tanto o objeto do discurso quanto os sujeitos que o enunciam são efeitos contingentes da relação que os forma e conecta.

Talvez seja conveniente enfatizar que, embora o presente trabalho dialogue de modo transversal com questões de gênero e sexualidade, ele não tem 
a pretensão de explorá-las diretamente. Gênero e sexualidade permanecem como problemas de fundo, se não pelo conteúdo do caso discutido, também pelo fato de que a antropologia das emoções é um campo intelectual que possui conexões genealógicas com os estudos em gênero e sexualidade. $\mathrm{O}$ objetivo aqui, contudo, é colocar em evidência como o discurso emocional de nossa interlocutora expressa micropoliticamente um questionamento de hierarquias - notadamente, operações de hierarquização que demarcam uma superioridade moral da heterossexualidade em detrimento de outras orientações sexuais, que tive oportunidade de discutir em ocasiões anteriores (Oliveira, L., 2011; 2013). Questionamento, nesse caso, não significa subversão ou reestruturação radical de relações, mas um tipo de objeção mais ou menos sutil que pode emergir no interior de contextos e situações sociais específicas (e que, por ser sutil e localizada, não é menos impregnada de poder).

É com essas perspectivas em mente que gostaria, aqui, de abordar a história de vida de Karine, ${ }^{1}$ uma jovem de 25 anos graduada na área de ciências sociais aplicadas. Karine residiu por toda a vida na Zona Norte do Rio de Janeiro, na mesma casa em que seus pais e seu irmão caçula. Percebe a si mesma como uma "pessoa típica" de "classe média", parte de uma "família típica" de classe média: um casal de profissionais liberais, com formação em nível superior, que tiveram um casal de filhos. Se apresenta alternadamente como "homossexual", "mulher gay" ou "lésbica", sem expressar preferência significativa por alguma dessas categorias. ${ }^{2}$

Conheci Karine através de outro colaborador da pesquisa - um jovem gay que integrava, junto com ela, uma rede de sociabilidade em que suas

1 Na apresentação de resultados da pesquisa, todos os nomes citados foram alterados, assim como informações que pudessem identificar diretamente quem são os entrevistados foram omitidas, de modo a resguardar sua privacidade.

2 Facchini (2008), em sua pesquisa com "mulheres que se relacionam afetiva e/ou sexualmente com outras mulheres" na cidade de São Paulo, assinala o modo como o uso de categorias de classificação autoatribuídas pode variar conforme a situação social e os sujeitos envolvidos. Muitas dentre suas entrevistadas expressam uma rejeição ao uso da categoria "lésbica", seja pela associação desse termo a uma intensa conotação estigmatizante, seja por um discurso de repúdio a rótulos e valorização da liberdade pessoal. Essa categoria, contudo, era mais adotada entre aquelas que tinham contato/proximidade com ideias do movimento LGBT - notadamente as mulheres mais jovens e pertencentes a estratos sociais mais elevados. Destaco, aqui, que as categorias acionadas por Karine para falar sobre si e sobre sua sexualidade são congruentes com sua afinidade e simpatia pelas agendas políticas LGBT. 
orientações sexuais eram conhecidas e explicitadas. Em geral, eu acompanhava os colaboradores da pesquisa naquelas situações cotidianas de sociabilidade em que eu fosse acolhido (como encontros em cafés, shoppings, bares, lanchonetes e praças públicas), aproveitando alguns desses encontros para realizar entrevistas registradas em gravador, mas participando também de conversas informais em outras ocasiões. Em nosso primeiro contato, em agosto de 2009, Karine manifestou certa reticência em colaborar com o projeto, e o interesse de que eu explicitasse em detalhe qual era o "referencial teórico" da pesquisa, e de que maneira eu pretendia interpretar os dados. A afirmação de que eu estava interessado em conhecer as experiências e as percepções de gays e lésbicas sobre a relação com suas famílias (dialogando com um conjunto relativamente amplo de perspectivas e estudos, e não propriamente com "um" único referencial teórico) foi considerada ambígua e insuficiente, demandando esclarecimentos adicionais: quais autores? Quais teorias, quais hipóteses? Demorei um pouco a compreender que essa reserva inicial, expressa de maneira relativamente amistosa, em essência não dizia respeito às correntes teóricas com que eu estaria ou não dialogando, mas a potenciais usos políticos que poderiam ser dados às interpretações produzidas. Por sinal, essa postura de reticência se dissolveu quando, em algum momento, mencionei minha vinculação prévia com o Centro Latino Americano em Sexualidade e Direitos Humanos (Clam/Uerj) e a atuação em projetos de pesquisa preocupados com a promoção da igualdade de gênero e direitos sexuais, que ocorreu paralela à minha atuação como professor em projetos voltados à promoção do debate sobre gênero e diversidade na educação. Em ocasião posterior, Karine verbalizou de forma mais explícita os motivos de sua reserva: ela se negaria, terminantemente, a participar de estudos cujas premissas ou resultados pudessem de algum modo reforçar estereótipos, visões "negativas" ou "patologizantes" da homossexualidade. Convém lembrar que na primeira década do século XXI ganharam corpo turbulentas controvérsias públicas em torno do "direito" reivindicado por certos psicólogos de oferecer "tratamento" e "terapias" para "cura da homossexualidade" - é possível que essa reticência diante de "pesquisas científicas" em geral tenha alguma correlação com a reverberação desses debates.

Discutir histórias de vida sob uma perspectiva antropológica comporta um conjunto próprio de desafios e resultados teórico-metodológicos. Como sugere 
Gonçalves (2012), a construção "pessoas-personagem" no interior de "etnobiografias" evidencia o caráter narrativo tanto do relato biográfico quanto da etnografia que o inscreve. $O$ discurso sobre si não é produzido a partir de um self preexistente, mas é construído a partir de compreensões convencionais acerca do que é uma "pessoa"; paralelamente, há um componente de criatividade decorrente do fato de que esses discursos em que a vida do narrador é o foco estão sempre articulados a cenas e situações específicas em que outras pessoas-personagens comparecem. Uma história de vida será sempre construída com o pesquisador dentro de contextos locais nos quais ele próprio comparece como uma espécie de personagem - nem que seja no papel de um ouvinte, que é percebido de tal ou qual maneira pelo narrador. Esse tipo de abordagem propicia uma alternativa à antinomia clássica que opõe indivíduo e sociedade, pois coloca em evidência modos possíveis de individuação a partir da elaboração de convenções culturais em narrativas sobre situações sociais.

Os pais de Karine comparecem como personagens importantes no relato discutido adiante. Não tive oportunidade, à época, de conversar com eles e de ouvir suas narrativas a respeito dos eventos narrados pela filha (ainda que tenha trabalhado, na pesquisa mais abrangente, com uma análise do discurso de mães de homossexuais). Talvez tivesse sido possível negociar esse acesso, mas eu tinha certa preocupação ética de que interpelá-los diretamente poderia favorecer um confronto aberto de perspectivas e potencializar tensões existentes entre a jovem e sua mãe. Esse caso evoca um desafio teórico-metodológico particularmente significativo: embora a tradição antropológica tenda a conferir muita atenção ao "discurso nativo", a construção da realidade não é feita somente de discursos, mas também de silêncios investidos de sentido (Bispo, 2016). Como veremos adiante, não somente o discurso, mas também o silêncio da mãe é especialmente significativo para Karine. $O$ contraponto com as perspectivas de seus pais poderia, decerto, iluminar algo a mais sobre as dinâmicas familiares vivenciadas por pessoas LGBT, mas não elimina o fato de que as experiências narradas pela filha contêm um comentário micropolítico sobre o modo como esta percebe seu lugar na família e no mundo. É desse comentário, socialmente situado e posicionado, que desejo tratar aqui. Nas páginas que se seguem, desejo discutir como Karine aciona discursos emocionais ao falar sobre sua sexualidade e sua relação com a família, com especial atenção para desdobramentos da revelação de sua orientação sexual para os pais. 


\section{Memórias da injúria: a construção de uma "mágoa"}

Começo evocando o depoimento de minha interlocutora sobre experiências vividas na juventude, no qual um discurso emocional comparece na evocação e narrativa de certos eventos considerados por ela mais significativos. A descoberta da sexualidade, para Karine, foi um "processo interrompido". Por volta dos 12 anos de idade, sentia "tristeza" e "frustação", por não corresponder a certos estereótipos acerca do gênero feminino, mas sem ter muita consciência do motivo desses sentimentos: ela sempre fora uma "menina-moleca, uma tomboy", ${ }^{3}$ que gostava de bola de gude e futebol, e de roupas masculinas. Karine conta que, embora sentisse certa tensão no ar, nunca sofreu censuras diretas na família, ao longo da infância, por essas condutas que transgrediam convenções sobre o gênero feminino. Na adolescência, "ficou" com outra jovem de sua faixa etária (uma experiência que classifica como "absurdamente intensa", e com a qual não conseguiu "lidar" naquela época): "Eu me fechei, dei um jeito de me convencer de que aquilo tinha sido uma experiência pontual, e não quis mais falar com a menina." Afirma que, após o evento, sua sexualidade permaneceu "congelada" por cinco anos: tinha "medo" de refletir sobre o significado dessas experiências, não dispunha sequer de um "vocabulário" para isso. Considera que, até então, o vocabulário a seu alcance para nomear esse tipo de desejo e prática estava associado a "xingamentos": termos como "viado" (no caso da homossexualidade masculina), "lésbica", "fancha", que eram empregados por seus colegas de escola, e que aludiam mais à transgressão das convenções em torno do gênero que à sexualidade em si. Para ela, essa restrição no vocabulário tornava difícil até mesmo "pensar" sobre desejos e experiências sexuais vividas com mulheres. Para exemplificar essa "limitação" linguística, relembra e relata uma cena que vivenciou na escola, quando tinha cerca de 12 anos de idade:

3 A categoria tomboy é uma expressão de língua inglesa, usualmente empregada para se referir a jovens do sexo feminino que apresentem aparência e maneiras consideradas, em um dado contexto, "masculinas". Segundo Butler (1993, p. 154-155), essa palavra era aplicada no século XVI aos meninos, mas começa no século XVII a ser usada pra se referir a meninas, especialmente aquelas mais agressivas e revoltadas. Por volta do século XIX, o rótulo tomboy - que até então era uma categoria com conotações mais estritamente associadas ao gênero - passa a ser também associado à homossexualidade feminina. 
Eu me lembro que uma vez na escola eu estava fazendo algum tipo de atividade, eu acho que a gente estava jogando algum tipo de jogo, tinha meninos e meninas jogando. E aí... [...] rolou uma briga, um menino me provocou, a gente discutiu e aí o menino ficou puto. Estava um dia quente, daí ele pegou e tirou a blusa. E quando ele tirou a blusa eu meio que fiquei meio atordoada, assim, meio que virei [o rosto] para o lado e aí todo mundo começou a rir. Aí uma menina virou e falou: "Ela é lésbica! Você vai ficar aí brigando com ela? Não perca seu tempo." Aí, eu falei assim: "Eu sou o quê? De onde vocês tiraram isso? O que é que vocês estão falando? O que vocês querem dizer?" Aí aquilo me magoou, mas eu não entendi muito bem. Aí depois eu fiquei pensando assim "o que será que significa isso? O que será que eu fiz que é coisa de ‘fancha'?" Daí eu fiquei um tempo remoendo aquilo e não consegui achar a resposta, não sabia dizer exatamente o que era, o que significava ser "fancha", naquele momento. Mas foi usado para me agredir.

O sentido da ofensa, implicada na acusação "você é lésbica", provém não só do significado investido nas palavras enunciadas, mas do modo como estas são proferidas e da situação da enunciação. Como sugere Julian Pitt-Rivers (1971, p. 17), em ensaio que aborda os códigos da "honra" e da "vergonha" em culturas de sociedades mediterrânicas, a presença física do ofensor exerce um papel crucial na emergência do sentimento de "ofensa":

A importância da presença pessoal é altamente relevante em matérias de honra. Aquilo que é uma afronta dito na cara pode não desonrar, dito pelas costas. Aquilo que é ofensivo geralmente só o é se alguém estiver presente para sentir a ofensa. O que é ofensivo não é o ato em si, mas o fato de obrigar o ofendido a assistir a ele.

Em essência, para um insulto funcionar enquanto insulto, ele precisa ser público; tais afrontas interpessoais à honra alheia são feitas para envergonhar, e se inscrevem no cerne das convenções culturais sobre a "vergonha". Ruth Benedict (1972, p. 188-189) abordou a vergonha em contraste com a "culpa", como ênfases específicas conferidas a certos estados emocionais em culturas distintas. A culpa implicaria responsabilização de si por certos atos, sendo eventualmente passível de expiação através de publicização (como no 
ritual da confissão cristã); a vergonha, ao contrário, pode se intensificar com a visibilização do evento que a provocou. Em uma distinta tradição teórica, Goffman (2012, p. 105-108) mostrou como o sentimento de "constrangimento" em situações de interação face a face comparece na manutenção de convenções e formas de organização coletiva, resguardando a possibilidade de que um indivíduo desacreditado possa em ocasião futura corresponder a expectativas geradas pelas impressões que terceiros têm sobre ele, favorecendo a preservação da distância entre categorias sociais. Trabalhos mais recentes retornaram a esse tema, explorando a articulação entre situações de interação social e contextos político-culturais: sentir vergonha perante alguém, compartilhar de vergonha coletiva ou de vergonha alheia, são formas de afirmação de vínculos sociais que implicam compartilhamento de identidade e valores (Ahmed, 2004; Miller, 1993). Retornaremos a este ponto - as articulações entre "vergonha" e "ofensa" - mais adiante, ao tratar da percepção de Karine sobre demonstrações de "vergonha" exibidas por sua mãe pelo fato de ter uma filha "lésbica".

A cena de conflito no ambiente escolar narrada por Karine poderia ser lida como uma pequena fábula moral que, à luz de uma perspectiva contextualista das emoções, possibilita um leque de interpretações distintas, porém complementares. Por um lado, a cena inscreve convenções culturais, vigentes em seu grupo de pares, que desqualificavam a diversidade sexual. É uma memória da injúria, a rememoração de atos de fala que, como sugere Eribon (2008), são talhados à força no corpo e na subjetividade daqueles que se descobrem alvos de injúria. Tais atos de fala são enunciados performativos que instituem uma demarcação entre o lugar social das pessoas ditas "normais", ocupado pelo sujeito da fala, e o lugar marginal daqueles que são objeto do discurso e do desprezo alheios. O relato de Karine, contudo, não parece ser uma mera evocação da injúria. Ele desloca ativamente a injúria de seu contexto original e reconfigura seu sentido, ao ser citada na situação proporcionada pela entrevista, recorrendo a uma retórica da queixa. Esses eventos não são narrados, apenas e simplesmente, porque geram "mágoa". Poderíamos, inversamente, sugerir que Karine se refere a eles como mágoas porque sente que eles merecem ser narrados, em um contexto político e cultural no qual a legitimidade dos atos que geraram mágoa é passível de questionamento. O depoimento não somente enuncia, mas denuncia: é uma queixa cujas condições de verbalização 
são a inscrição desses eventos na memória como mágoa, a percepção de que os colegas de escola usaram as categorias "lésbica"/"fancha" para agredi-la, e a existência de uma audiência receptiva. Como veremos adiante, esse tom de protesto também aparece na fala de Karine sobre certos conflitos com sua mãe.

No período que identifica como o "fim" de sua "adolescência", quando ingressou na faculdade, Karine teve dois "namoros" com rapazes que duraram cerca de três meses. Ela afirma que essas experiências com o sexo oposto estavam fadadas ao fracasso, mas que na época não era capaz de perceber isso. Com o ingresso na graduação, em um prestigioso curso de uma prestigiosa instituição de ensino carioca, começa a ter amigos gays e lésbicas - fato que associa ao processo gradual pelo qual começou a "se soltar". Como veremos a seguir, ela retrata esse período como um momento decisivo em sua vida, que impactou sua relação com a família.

\section{“E ficou claustrofóbico lá dentro...": o namoro e a experiência do armário}

Karine considera que é na faculdade que a maioria das pessoas "assume" a própria homossexualidade. Ao ingressar na graduação, se viu subitamente cercada por um círculo de colegas que tratavam desse tópico com "naturalidade" e franqueza. Passou a frequentar "festas alternativas", voltadas para um público de diferentes orientações sexuais, incluindo gays e lésbicas. Nessa época, com cerca de 21 anos de idade, Karine se questionava acerca de sua sexualidade, e pensava que talvez fosse "bissexual", tendo inclusive se apaixonado por uma jovem "bissexual" com a qual não chegou a ter qualquer envolvimento. Aos 23 anos, teve seu primeiro "namoro" com uma mulher; pouco depois, "saiu do armário" e revelou sua orientação sexual para a família (primeiramente, para o irmão, e em seguida para seus pais). Afirma que esse "namoro" se iniciou de forma muito súbita - e para ilustrar, conta uma piada, descrevendo aquilo que as lésbicas levam consigo para um "segundo encontro": as malas, "já para se mudar" (os homens gays, em contraste, não levariam nada, pois nunca chegavam a ter um "segundo encontro"). Como veremos adiante, o namoro é uma experiência investida de relevância significativa no contexto da revelação intencional da orientação homossexual. 
Na família de Karine, sempre circulou muita "informação" sobre "sexualidade" - tocante a contracepção, prevenção de infecções sexualmente transmissíveis e à importância do uso do preservativo. Essas "informações" eram compartilhadas tanto com ela quanto com seu irmão, de forma indistinta. A "homossexualidade" era eventualmente tematizada nessas conversas no ambiente doméstico - não como algo que poderia estar presente na própria família, mas como um aspecto da sociedade ou da vida de terceiros: "Olha aquela pessoa ali, que apareceu na novela." Tais conversas nunca versavam sobre as experiências pessoais dela e do irmão. Desse modo, Karine não se sentia obrigada a contar nada sobre sua sexualidade para seus familiares. Ela teve algumas experiências sexuais com mulheres, antes de seu primeiro namoro, e considerava que estas não eram um assunto que precisasse ou devesse ser compartilhado em família - do mesmo modo que seu próprio irmão, até onde ela tem conhecimento, não falava sobre as experiências sexuais dele. Contudo, ao contrário das experiências sexuais vistas com assunto estritamente privado - as experiências amorosas são consideradas algo que pode e deve ser publicizado. O ingresso em um "namoro" é, assim, retratado como uma experiência que a motiva a "sair do armário:

Quando eu comecei a namorar ficou complicado porque começa a namorar e isso não é uma coisa que você consiga esconder, não é, que você consiga "não falar" sobre. É um relacionamento que você vê a pessoa com frequência, está sempre com a pessoa. $E$ isso começou a me... a sofrer, o fato de que eu não podia falar sobre isso, eu me sentia trancada dentro do armário mesmo, trancada no armário. $\mathrm{O}$ armário ficou pequeno para mim, foi nesse momento que o armário ficou pequeno. E ficou claustrofóbico lá dentro. Eu queria poder falar, queria falar que eu tinha namorada, que a gente ia no cinema, sabe? Poder apresentar minha namorada e poder falar das coisas boas e das coisas ruins, "nossa, minha namorada tá chata hoje" ou "nossa, minha namorada tava linda hoje", né, como qualquer pessoa faz.

No trecho acima, o ingresso em um namoro aparece como fator que motiva a revelação da orientação sexual para a família, no interior de um discurso nitidamente pontuado por categorias emocionais e alinhado a uma visão de mundo igualitária, em que o silêncio compulsório é sentido como desconfortável restrição. Karine ansiava poder falar abertamente sobre suas experiências amorosas, como qualquer pessoa faz. Essa aspiração tem lugar de destaque dentre as 
motivações para a revelação. Parece haver uma preocupação mais explícita, por parte de Karine, com seus próprios sentimentos do que com os sentimentos de seus pais. Isso não significa, de modo algum, indiferença às emoções materna $\mathrm{e}$ paterna; como veremos adiante, a reação de seus pais é objeto de intensa atenção. Contudo, as emoções dos outros são encaradas a partir de uma lente que valoriza a subjetividade do observador: a situação de não poder falar sobre essas experiências pessoais é o que faz Karine sofrer, a sentir-se claustrofóbica, constrangida em sua liberdade pessoal pelos limites do armário.

A noção de "armário" sinaliza para um aparato político-cultural que atinge pessoas homossexuais com um conjunto de injunções contraditórias, prescrevendo simultaneamente a exposição compulsória e a manutenção do segredo sobre si (Pollak, 1990; Sedgwick, 2007). De um ponto de vista macroestrutural, o dispositivo do armário tenta instituir uma fronteira clara entre uma categoria de pessoas ditas exclusivamente heterossexuais e todas as demais (quer estas estejam dentro ou fora do armário); ele não expressa um problema inerente à experiência dos próprios homossexuais, mas, pelo contrário, existe a serviço daquelas pessoas que pretendem demarcar sua identidade em oposição à deles. Sob um prisma fenomenológico, por outro lado, se descobrir "dentro do armário" significaria estar sujeito a uma espécie de duplo vínculo, no sentido atribuído por Bateson (1972) a essa expressão: um paradoxo lógico investido de intenso significado emocional, deflagrado por duas prescrições contraditórias (mutuamente excludentes, que gerariam consequências graves se não fossem ambas atendidas), que despontam acrescidas de uma terceira prescrição que impede a pessoa de ignorar as duas anteriores. Embora a publicização da orientação sexual para a família seja, para Karine, um processo investido de relevância e pontuado por discursos emocionais, essa ânsia por liberdade de expressão, que seu relato evoca, parece ir além da "obrigação de confessar" a verdade sobre a sexualidade cuja gênese histórica foi explorada por Foucault $(1988,2001)$. Esse discurso, que evoca algo quase da ordem de uma expressão obrigatória dos sentimentos (Mauss, 1980), poderia ser interpretado como parte integrante de certas "tecnologias de si" contemporâneas que colocam não somente o sexo, mas o discurso emocional em seu centro.

Um aporte para a compreensão dessa atenção cultural à emoção pode ser extraído de Duarte (1999). Em uma releitura do pensamento de Foucault, à luz da análise de Colin Campbell (2001) sobre a centralidade da emoção na ética 
romântica hedonista que se configura no século XIX, Duarte argumenta que o Ocidente moderno implantou um "dispositivo de sensibilidade" que atribui preeminência a sensações e experiências pessoais na constituição dos sujeitos, apoiado em uma atenção à corporalidade e em uma aposta na perfectibilidade (possibilidade de aprimoramento) da vida humana. Tecnologias de si são procedimentos que possibilitam aos indivíduos realizarem, por si próprios, operações sobre sua alma/pensamentos/condutas visando uma transformação positiva (Foucault, 2004, p. 95). Na implementação do "dispositivo de sensibilidade" no Ocidente moderno, tecnologias de si sustentadas em discurso emocional teriam gradativamente conquistado um lugar de destaque nos processos de construção da pessoa.

O desconforto de Karine não derivava, propriamente, de ter que guardar segredo sobre sua "sexualidade". O que a faz sofrer é a impossibilidade de conversar com seus familiares sobre emoções vivenciadas em certas experiências importantes pra ela. O paradoxo notado por Pollak (1990), colocado pela obrigação simultânea de ocultar e confessar o "segredo" sobre a própria homossexualidade, não parece se configurar do mesmo modo nesse contexto. Por sob uma capa de persistência e continuidade histórica dos interditos contra a homossexualidade, o que se descortina aqui é um cenário interior um pouco distinto: 0 que esses interditos parecem obstruir, nesse caso, não é a "confissão" da orientação sexual, mas a possibilidade mesma de exposição de certos sentimentos, em um contexto onde circulam convenções prescrevendo que estes deveriam ser expressados (por exemplo, poder se queixar sobre situações desagradáveis vividas com a namorada, ou expressar satisfação ante situações agradáveis).

Convém destacar a relevância de que a expressão pública de afeto pode, direta ou indiretamente, se revestir nesse contexto. Em depoimentos de gays e lésbicas que assumiram a orientação sexual para a família de forma mais ou menos espontânea ou voluntária, é possível identificar diversas situações e motivações subjacentes à situação da revelação. O ingresso em um "namoro" com uma pessoa do mesmo sexo, em especial, é uma experiência que comparece com alguma insistência em relatos sobre cenas de revelação da homossexualidade para a família de origem. O "namoro" parece, aqui, ser algo que existe para ser visto: é a expressão pública de algum tipo de compromisso e/ou dos "sentimentos" que o motivam. As convenções culturais que o diferenciam de outros modos de relacionamento fomentam a expectativa de que ele se 
faça acompanhar de algum grau de exposição e publicização. Para além de quaisquer dificuldades operacionais porventura envolvidas no trabalho de ocultamento de uma relação desse tipo, parece haver (ao menos para algumas pessoas) uma incompatibilidade entre segredo e namoro, que possivelmente se acirra com a duração e consolidação da relação. Em resumo, um namoro é algo que tais sujeitos não querem manter em segredo. Torná-lo público é confirmar que este "ê", de fato, aquilo que se pretende que ele seja. A existência de constrangimentos externos que obstruem esse processo de publicização do namoro pode incomodar bastante a gays e lésbicas que compreendam que deveriam, em sua vida afetiva e relacionamentos amorosos, desfrutar dos mesmos privilégios de visibilidade que são franqueados aos namoros heterossexuais. ${ }^{4}$ Esse tipo de incômodo pode, por um lado, ensejar manifestações organizadas na esfera pública, como os "beijaços", eventos dedicados a contestar essa distribuição de privilégios considerada pouco equitativa. Mas pode, também, ser expresso em um plano micropolítico, na vida privada e experiências interpessoais cotidianas. A permanência ou a saída do armário não diz respeito somente a formas de gestão racional da informação sobre si, mas também a experiências emocionais que podem ser bastante intensas (o "medo" das consequências da revelação, o "sofrimento" ensejado pela manutenção do segredo, a "coragem" para sair do armário, etc.). Se trata, de fato, de um dispositivo emocional de gestão da informação e de constituição de si mesmo em situações de interação social. Como veremos adiante, a revelação da orientação sexual é condição necessária, porém não suficiente, para assegurar esse tipo de expressão de si no espaço doméstico; ela requer todo um trabalho de reconstrução da definição da situação na casa, que implicará em diversos momentos o recurso a discursos emocionais.

\section{A (in)definição da situação na revelação para a família}

Retomemos o fio condutor da história de vida aqui analisada. Karine e sua namorada tocavam juntas em uma banda de rock. Um dia, decide levar seu irmão para assistir a um show do grupo. Após o show, apresenta Bianca a

4 Sobre esse ponto, ver a reflexão de L. Oliveira (2011) sobre a visibilidade da diversidade de gênero e da variação sexual e o tema da exposição pública de afeto entre pessoas do mesmo sexo. 
ele, como sua "namorada" - procurando tratar desse tema com naturalidade. Embora não soubesse qual seria a reação do irmão ao saber que ela estava namorando outra mulher, sua expectativa (posteriormente comprovada) é de que essa reação seria positiva:

Eu não queria fazer disso um assunto, tipo "sente aqui, meu irmão, precisamos conversar". Eu queria apresentar ela igual eu apresentaria um namorado, com uma naturalidade. E claro que eu fiquei nervosa porque eu não sabia como ele ia reagir, né, mas eu achava que ele ia reagir bem. E foi superótimo, supernatural. Foi até mais natural do que eu imaginava. Não teve um momento depois de conversa, sabe, e até depois quando eu cheguei a discutir alguma coisa com a minha mãe, meu irmão depois vinha conversar comigo e me apoiava, então com o meu irmão foi super... sei lá. Acho que é uma coisa de geração. A nossa geração tem mais contato com isso, e tem menos questões, menos problemas.

Após cinco meses de namoro, decide contar para o restante da família sobre essa relação, e discute a decisão com sua parceira antes de prosseguir. A namorada mostrou-se reticente e apreensiva, temendo que os pais de Karine - especialmente a mãe - brigassem com a filha. Karine responde à companheira que, de fato, não sabe como seus pais poderiam reagir, mas que precisava ter essa conversa com eles. $\mathrm{O}$ depoimento apresenta a cena da revelação para os pais como um evento breve, colorido pela aparente objetividade com que Karine abordou o assunto, e pela reação de mutismo dos pais:

Cheguei em casa com a roupa de trabalho e tudo, né, sentei na mesa e falei, sentei na mesa na frente deles e eles estavam no sofá vendo televisão e falei: “Mãe, eu preciso falar uma coisa com vocês, mas eu preciso falar rápido, senão eu vou perder a coragem, então não me interrompam." Aí meu pai falou: “Ai! Você foi presa?”, e a minha mãe falou: “Ail Você tá grávida?”... E aí eu falei: “Não, eu não fui presa; e não, eu não estou grávida. Muito pelo contrário. Faz cinco meses que eu estou namorando uma menina." Ponto. Parei. Os dois não responderam absolutamente nada, ficaram lá parados, meio que em estado de choque, não falaram nada. E eu falei: "OK, eu vou dar um tempo para vocês. Eu vou sair agora, vou na casa de uma amiga, eu tenho que terminar um trabalho de faculdade e até amanhã isso tem que estar pronto. Eu tô levando meu celular, se vocês quiserem conversar comigo 
eu estou no celular, senão a gente se vê quando eu voltar. Eu vou dar um tempo para vocês." Aí eu levantei e saí. Daí foi isso. No dia seguinte ninguém falou sobre o assunto.

A necessidade de "falar rápido" para "não perder a coragem" merece um breve comentário. Uma situação que demanda coragem para ser enfrentada é, de fato, uma situação que provoca medo (Miller, 2000). Até mesmo no contexto da revelação para o irmão, considerado de antemão mais receptivo, Karine se sentiu nervosa. Ao contrário da situação "natural" em que apresentou a namorada ao irmão (o concerto de rock em que sua namorada estava presente), a revelação para os pais ocorre no centro de uma conversa formal, reservada exclusivamente para isso, e parece ser fonte de ansiedades mais intensas por parte da jovem. A afirmação de que "não sabia como os pais reagiriam" expressa mais do que desconhecimento ou ausência de informação: sinaliza também para o medo da reação que os pais poderiam eventualmente ter. Esse discurso assinala, nitidamente, uma sensibilidade da jovem a tensões geracionais e a preconceitos culturais que ela antecipa que poderiam se manifestar naquela situação, e é sugestivo do trabalho emocional (Hochschild, 2013) demandado para transformar o medo inicial da reação dos pais em "coragem".

Sob outro prisma, o silêncio poderia ser encarado como uma resposta ritual dada pelos pais, no microcosmo delineado por essa cena, ante um curso de ação inesperado assumido pela filha, que rompe a linha e a fachada (Goffman, 2012) exibidas por ela na esfera doméstica até aquele momento. $\mathrm{O}$ "silêncio" é um gesto que pode ter muitos significados. Se considerarmos, contudo, que sob outros aspectos, a rotina da família após aquele momento não foi alterada, se poderia sugerir que, socialmente, o silêncio funciona nesse contexto como uma forma de preservação das relações, diante de uma súbita alteração na definição da situação.

A noção de definição da situação é introduzida por W. I. Thomas (1923) em uma reflexão teórica sobre a capacidade que os sujeitos têm de tomar decisões por si mesmos - abordagem que (em retrospectiva) parece precursora de tentativas posteriores, no campo da teoria social, de superação da antinomia entre "indivíduo" e "sociedade" através do foco em formas relacionais de agência. O cerne do argumento do autor é que as ações humanas não são meramente "determinadas" a partir de fontes exteriores. Elas seriam influenciadas pelo modo como sucessivas situações vividas pelo sujeito são definidas em relações interpessoais, em um 
processo que modela a conduta e a personalidade dos indivíduos, de tal maneira que os "desejos" individuais seriam progressivamente "regulados" em sociedade:

Anteriormente a qualquer ato de comportamento autodeterminado, há sempre um estágio de exame e deliberação que podemos chamar de definição da situação. E, de fato, não apenas os atos concretos dependem da definição da situação, mas gradualmente toda uma política de vida, e a personalidade do indivíduo em si mesmo, derivam de uma série de definições desse tipo. (Thomas, 1923, p. 42, tradução minha, grifo do autor).

Esse estilo de teorização, em vez de explicar a conduta humana pela ascendência de instituições sociais previamente estabelecidas, considera que tanto as personalidades individuais quanto as próprias instituições derivam de sucessivas definições da situação. O sentido atribuído a situações vivenciadas é mutável: embora a reiteração de experiências semelhantes em situações semelhantes possa ensejar a constituição de códigos de conduta mais ou menos estáveis, estes estão abertos a transformação, sempre que uma situação inesperada demandar definição. Trata-se de ferramenta rentável para a reflexão sobre mecanismos informais de regulação das condutas e de ação coletiva, como, por exemplo, aqueles em jogo nas turbas/multidões e na gossip/fofoca (Thomas, 1923, p. 44-50). Essa perspectiva nos permite compreender as situações como espaço de constituição e locus da mediação entre "indivíduo" e "sociedade".

A abordagem de Thomas, para além de sua eventual relevância para a história da teoria social, é pertinente para a análise conduzida neste artigo. Embora não haja uma reflexão sobre o estatuto teórico das emoções em sua obra, as emoções desempenham papel de destaque em sua discussão sobre a definição das situações. Exemplo disso é o argumento de que uma comunidade pode, pelo uso de categorias ofensivas (e, notadamente, na prática da fofoca), "conectar o opróbrio a pessoas e atos empregando epítetos que são, simultaneamente, concisas e emocionais definições da situação" (Thomas, 1923, p. 49, tradução minha, grifo meu). Do mesmo modo, diferentes tipos de gesto e sinais de repúdio integram também a linguagem empregada na definição de uma situação, "dolorosamente sentidos como reconhecimento desfavorável" (Thomas, 1923, p. 50, tradução minha), como uma depreciação no/do status da pessoa. 
O que desejo ressaltar, aqui, é o modo como discursos emocionais comparecem na definição da situação. Na cena de revelação da orientação sexual por Karine, ocorre uma primeira perturbação na definição da situação no espaço doméstico no momento em que ela declara ter algo "importante" para contar, que demandava "coragem" para ser contado. Como sugere Strauss (1999), quando as pessoas envolvidas identificam de forma quase imediata a situação que está ocorrendo, elas podem coordenar suas ações mútuas de tal maneira que essa definição inicial da situação seja preservada. Não se coloca em questão "quem" cada um é nessa situação; todos os participantes têm uma ideia de quais facetas de sua própria identidade poderiam ser acionadas. Esse acordo tácito, contudo, só é possível quando todos se encontram desempenhando atividades convencionais. Se alguém age de forma inesperada, isso torna a situação problemática, gerando um problema de definição: “O que está acontecendo aqui?" Os envolvidos não sabem como devem agir, não sabem como agir naquela cena, e no limite, podem não saber "quem" eles são ou deveriam "ser", naquela situação específica.

Se a definição da situação é ambígua, isso leva a um esforço para decifrar as motivações por trás da conduta inesperada do outro: suposições, "palpites", perguntas. A dúvida do pai de Karine, questionando se a filha estava vivenciando conflitos com a lei, e a dúvida da mãe, perguntado se a filha estava grávida, expressam implicitamente expectativas destes sobre aquilo que a filha "é", e evocam um leque de problemas ou transgressões imagináveis e enunciáveis. É verossímil supor que o "namoro com uma menina" era uma afirmação relativamente imprevista naquele contexto - ou, se era de algum modo antevista, as convenções vigentes não permitiam sua verbalização explícita. A resposta adotada pelos pais ante a declaração de Karine poderia ser vista como uma forma de evitação (Radcliffe-Brown, 1940), que deixa um conflito potencial em suspenso em prol da manutenção de relações sociais. A evitação, nesse caso, é uma reação à súbita mudança na definição da situação no ambiente doméstico com a revelação de Karine.

\section{“Agressões sutis": silêncio, desconsideração e ressentimento}

Diante da postura de evitação assumida pelos pais, Karine reage com outra forma de evitação: vai para a casa de uma amiga, "dá um tempo" para os pais. Esta situação, contudo, é considerada bastante desconfortável por Karine 
- talvez pelo fato de que a inquietação que a mobilizou a revelar para os pais seu namoro com Bianca não fosse, propriamente, a necessidade de "confessar" sua orientação sexual, mas a ânsia por expressar seus sentimentos no cotidiano como todo mundo faz.

Jean-Jacques Courtine e Claudine Haroche (2007, p. 191-192, tradução minha) - em obra que aborda o modo como o rosto, fisionomia e expressões faciais passaram progressivamente a ser representados como um importante mecanismo de expressão e dissimulação das emoções entre os séculos XVI e XIX - apresentam uma interessante reflexão sobre o significado que o silêncio passa a assumir nas relações pessoais, nesse período em que o exprimir e decifrar das emoções do outro ganham cada vez mais relevância:

A regra do silêncio é clara: não devemos nos fechar ao outro. O rosto taciturno não convém senão aos espíritos melancólicos e infelizes. $O$ ar aberto e amável que recomendam muito mais as artes da conversação que os preceitos do silêncio, esta é a marca depositada sobre o rosto de cada um pelos paradoxos de uma sociedade civil onde se reforça o controle social ao mesmo tempo em que se autonomiza o indivíduo, quando tal sociedade é concebida como espaço de diálogo, de troca e de expressão.

O argumento dos autores é que, na modernidade, o silêncio se torna ao mesmo tempo objeto de um interdito, e uma forma paradoxal e poderosa de expressão em certas situações, pela ausência da fala em contextos nos quais é esperado que esta ocorra. O silêncio é simbólico, ele não apenas demanda interpretação, mas também sublinha o valor do diálogo. Nas relações amorosas, por exemplo, o poder do silêncio se faria sentir com especial força: o silêncio instaura um ferimento, para o qual as palavras são o consolo e remédio mais desejados (Courtine; Haroche, 2007, p. 200). Essa abordagem histórica oferece uma chave analítica bastante rentável para refletirmos sobre o poder de que o "silêncio" e seu rompimento podem ser investidos em situações micropolíticas deflagradas no ambiente doméstico pela revelação da homossexualidade.

O "silêncio" dos pais, como vimos, é fonte de intensa inquietação para Karine. Não basta dar sentido a ele, é preciso atuar ativamente visando a superação do silêncio na redefinição da situação. Uma de suas amigas, lésbica, a aconselha a não consentir que esse silêncio persista. $O$ conselho é baseado em 
experiência pessoal: a amiga atravessara situação semelhante, anos antes, e afirma que pagara um "preço alto" por não ter conversado abertamente com seus próprios familiares. Karine passa então a mencionar o nome da namorada em casa, naquelas ocasiões em que fosse encontrá-la: "Estou indo ao cinema com Bianca", ou "vou a uma festa com Bianca". Seus pais reagiam, invariavelmente, com silêncio. Passado algum tempo, expõe para seu pai que essa situação a inquietava. Ela ansiava por saber o que se passava pela cabeça de seus pais, e o modo como sua orientação sexual era vista por eles:

E a gente saiu para conversar, eu e meu pai. E meu pai foi ótimo, foi lindo. Ele sentou e falou: "Olha, eu não tenho menos problema com isso. Eu acho que não tem que ter problema [algum] com isso. Estou orgulhoso de você ter tido coragem de seguir o que realmente vai te fazer feliz, e não tenho o menor problema com isso. Mas a sua mãe está tendo um pouco de dificuldade, e ela não quer falar sobre esse assunto. Ela avisou pra mim que ela não quer falar sobre esse assunto." Aí eu falei: "Pai, eu entendo que a mamãe tenha dificuldade pra falar sobre esse assunto, eu demorei cinco, seis anos pra sair do armário para mim mesma, mas [...] eu dou o tempo que ela precisar, mas a gente precisa conversar. A gente precisa do mínimo de troca." Aí depois de um tempo a gente começou a falar bem devagarzinho, bem devagarzinho. Minha mãe não é muito aberta a falar sobre isso, mas hoje em dia não tem o menor problema. Ela fala sobre isso, eu falo sobre isso. Com mais restrição do que com meu pai, mas tranquilamente. Depois de um tempo as coisas se acertaram. Durante algum tempo eu fiquei bem brava com ela, especialmente por causa dessa coisa da minha sexualidade porque eu achei que ela estava sendo egoista, preconceituosa e etc. Com o meu pai, sempre foi mais tranquilo, porque o meu pai tem uma outra personalidade, ele é mais calmo [...]. E como ele não teve uma reação ruim como a da minha mãe, a gente não teve esse período de ficar afastado.

Inicialmente, a jovem julgou que sua mãe estivesse agindo de uma forma "egoísta", "preconceituosa", e ficou "brava" com ela por causa disto. Afirma que a relação com a mãe, antes disto, já era relativamente conflituosa - mais tensa do que a relação com o pai, que sempre foi uma pessoa "tranquila". Acredita que essas diferenças de "personalidade" entre seu pai e sua mãe, e a diferença no modo como se relacionava com os dois, nuançaram o modo como eles reagiram ao saber sobre sua orientação homossexual. 
Karine considera que, além dessa tensão manifesta nas situações de silêncio, não houve grandes mudanças em sua relação com a família a partir da revelação da homossexualidade. Os pais habitualmente regulavam sua circulação fora do ambiente doméstico. Queriam saber que lugares ela frequentava, em quais festas ela estava, na companhia de quais pessoas - um tipo de regulação já notado em outros estudos focando a relação entre pais e jovens adultos residindo em um mesmo núcleo doméstico (Ramos, 2006). Eles se preocupavam caso ela chegasse muito tarde, à noite, e recomendavam que ela não andasse de carona com pessoas que tivessem ingerido bebidas alcoólicas; nomear essas pequenas obrigações como expressão emocional de zelo (preocupação) é uma forma de reconhecer sua relativa legitimidade, ainda que tais recomendações não fossem estritamente observadas. Havia, em especial, uma censura ao pernoite fora do espaço doméstico. Karine acredita que essas censuras não tinham relação com sua sexualidade, e sugere que se trata de uma característica da cultura local das adjacências do tradicional bairro carioca de classe média em que foi criada:

Eu acho que é uma cultura meio [do bairro tal], viu? Vou te falar... Tem duas amigas minhas que são héteros, uma é casada e a outra é super, namora há 20 milhões de anos, e os pais são do mesmo jeito. Não é porque eu sou gay ou não sou, sabe. Elas falam, inclusive a minha amiga que casou, ela fala que uma semana antes do casamento ela não podia dormir na casa do namorado dela porque "imagina o que que os porteiros vão dizer!...", e coisas do tipo. Então a argumentação era que "isso não se faz", que isso seria perder totalmente o controle, que era perder o respeito, sei lá. Também não era muito discutido, não, só era um "problema". Só do tipo... "Não, não senhora! A senhora vai voltar pra casa tal hora." Não era muito argumentado, até porque não tem muito argumento. Acho que era um senso antigo, assim, de que se você dormir fora de casa você está se desvalorizando, ou "o que é que as pessoas vão pensar?", se estiver chegando de manhã, sabe, com o cabelo amarrotado, no prédio...

Karine comenta que tanto ela quanto o irmão eram igualmente "regulados": os pais não gostavam que seu irmão "dormisse fora", havia um tratamento "igualitário" dispensado a ambos os siblings. Do mesmo modo, não havia hábito de que amigos dela ou dele frequentassem a casa: a presença de visitas era relativamente rara. Em algumas ocasiões, sua namorada visitou sua casa. Karine 
compara e contrasta o tratamento que seus pais davam à sua namorada ao modo como ela própria era recebida na casa da companheira:

No primeiro ano que eu estava namorando, eu cheguei na minha casa e falei: "Olha, eu queria jantar com todo mundo, e todo mundo inclui a minha namorada." Eu falei com o meu irmão, eu estava viajando e falei: "Arranja isso aí com os meus pais. Fala pra eles que a gente vai jantar juntos." Aí, de vez em quando a gente fazia esse tipo de coisa, mas era bem de vez em quando. Eles sabiam quem ela era, eu apresentei e tal, mas não tinha essa sociabilidade. Já na casa dela, não. Eu ia lá sempre, sei lá, dia sim, dia não; a mãe e o padrasto dela sabiam quem eu era, e falavam comigo normalmente, o irmão também. Era muito mais aberto nesse sentido.

Hoje, Karine tem uma bandeira do arco-íris em seu quarto, e embora não seja membro de grupos politicamente organizados de defesa dos direitos LGBT, se considera uma pessoa "supermilitante" e é consumidora ávida de literatura do campo da teoria queer. Considera que a relação com os familiares melhorou bastante ao longo do tempo, desde o dia em que "saiu do armário", mas nota a persistência de certas tensões tocantes à sua orientação sexual, notadamente na relação com a mãe. Os conflitos com a mãe são mencionados como uma forma de "agressão sutil" - com destaque para uma situação específica, na qual a mãe teria expressado "vergonha" pelo fato de ter uma filha "lésbica":

Primeiro foi o choque do silêncio, né. Foi a reação de choque que eles tiveram de não querer falar sobre isso, e de achar que isso é uma coisa sobre a qual não se deve falar. Ninguém me agrediu, ninguém me bateu, mas aquilo machucou como se fosse uma violência. Com meu pai, depois de um tempo, a situação se remediou, porque a gente conversou e deixou tudo bem esclarecido, e eu consegui aceitar também o que ele estava sentindo. Mas com a minha mãe, eu não conseguia aceitar o que ela estava sentindo. Na verdade, eu não sabia o que ela estava sentindo, até o meu pai dizer: "Olha, ela está tendo problemas pra lidar com isso, e ela não quer falar sobre isso." Com minha mãe, teve um episódio que eu me senti meio... [...] eu me senti pessoalmente ofendida. Aconteceu um problema lá no condomínio, e aí eu e minha mãe acabamos discutindo sobre a coisa de eu ser gay... E daí a minha mãe falou assim pra mim: "Não fica na portaria..." Aí eu disse: "Poxa, mãe. As pessoas ficam na portaria. A guria sempre fica com o namorado... estão se 
despedindo." Daí eu vi ela nervosa, fechando a janela. Eu vi que ela não queria que isso virasse um assunto para as outras pessoas no prédio. A princípio, eu achei que ela estava temendo que as outras pessoas fossem ser preconceituosas com ela e comigo. Depois, eu conversei com ela: “Ué, mãe, mas eu sou gay. As pessoas não sabem que eu sou gay? Você acha que as pessoas do prédio, da rua não sabem que eu sou gay? Eu ando de mão dada com a minha namorada, e eu ando de mão dada com a minha namorada até aqui, na porta de casa. E até por isso eu fico aqui na portaria. Os héteros podem ir na praça, no cinema..." Daí eu comecei a discutir esse assunto e aí ela começou a fechar a janela, como quem diz "não fala isso alto". Eu senti que aquilo não era pra me proteger, não era algo do tipo "não fala isso que as pessoas podem ser preconceituosas com você". Era mais uma coisa do tipo "eu tenho vergonha, não quero lidar com isso". Esse tipo de agressão sutil..., eu acho que é o que mais acontece lá em casa. Nunca verbalmente, direto - do tipo "sua fancha, que coisa absurda" - até porque se isso acontecesse, acho que ia ter briga. Mas é uma coisa sutil, sugerindo que isso [a homossexualidade] é uma coisa que se deve ter vergonha. O que é também um tipo de violência, porque está dizendo que a sua orientação sexual tem alguma coisa de ruim de alguma forma, que deve ser escondida. E o problema não era com o preconceito, entende? Você se preocupa com a pessoa porque você fica com medo, claro, de a pessoa ser agredida. Mas eu acho que o problema não é a proteção, a preocupação com o preconceito. Acho que as coisas melhoraram muito ao longo do tempo, acho que hoje em dia isso acontece bem menos. Principalmente a minha mãe, né. Ela percebeu que eu não me tornei uma pessoa ruim, ou louca, sabe? Que não era o estereótipo múltiplo que ela tinha na cabeça dela, do que era uma mulher gay, sei lá.

No depoimento de Karine, o denominador comum presente em diferentes formas de "violência" parece ser sempre a reação negativa à visibilidade de uma conduta que não corresponde a certas convenções culturais: na relação com pares na juventude, gostos e envolvimento com atividades desportivas associados ao gênero masculino; mais recentemente, a exposição pública de afeto por pessoa do mesmo sexo em um "namoro". Inicialmente, Karine reporta o silêncio dos pais como algo que a "machucou"; a jovem se sente chocada com a reação de choque dos pais. Esses eventos geraram, certamente, problemas de definição da situação do ponto de vista da própria Karine: como ela relata acima, ela própria não "sabia" o que a mãe estava sentindo, até seu pai lhe 
contar que ela estava tendo dificuldades para lidar com a orientação sexual da filha e que não queria conversar sobre o assunto. Logo em seguida, ela relata, como verdadeiro insulto, uma situação de conflito em que sua mãe expressara "vergonha" por ter uma filha lésbica. Ela não queria que a filha fosse vista com a namorada na portaria do prédio, e também não queria que os vizinhos percebessem o embate que estava sendo travado na casa em torno desse tema. Essa atitude da mãe fez a jovem se sentir "pessoalmente ofendida". Se a conduta da mãe tivesse sido enquadrada como preocupação com o bem-estar filha, talvez pudesse ser justificável, mas a vergonha (preocupação com o juízo moral de terceiros) é considerada inadmissível.

Essa situação, em particular, é extremamente rentável para introduzir uma reflexão sobre o que é uma "ofensa", e sobre a relação entre essa categoria e as ideias de "agressão" e "violência". Os nexos entre essas noções são abordados em texto do antropólogo Luis Roberto Cardoso de Oliveira (2008), a partir de pesquisa que analisa, através da comparação entre três contextos nacionais, a relação entre ideias sobre "respeito" a direitos universalizáveis e de expressão de "consideração" ao cidadão que é marcado por sua singularidade pessoal. O autor defende que, embora aquilo que é rotulado como "violência física" possua um caráter material inegável e a "ofensa" seja um fenômeno imaterial e simbólico, existe muito mais possibilidade de se encontrar fundamento objetivo para a "ofensa" do que para a "violência física". O argumento é provocador: o autor sugere que "na ausência da 'violência moral', a existência da 'violência física' seria uma mera abstração” (Oliveira, L. R. C., 2008, p. 135).

A noção de "violência moral" remete a um "insulto" que envolve algum tipo de rebaixamento da parte "insultada", que no contexto brasileiro é expresso através da oposição entre consideração e desconsideração. $\mathrm{O}$ "insulto moral" tende a ser retratado como menos material ou real que a "violência física", e, desse modo, acaba invisibilizado no nível das instituições jurídicas. Está frequentemente associado à expressão de "sentimentos": uma "fenomenologia do fato moral" mostra o lugar do "ressentimento" na percepção de um evento enquanto "insulto". Um ato de violência física não intencional pode provocar tanta "dor" quanto um ato intencional, mas não desperta na vítima o mesmo ressentimento que é experimentado diante de uma agressão deliberada. O insulto moral é uma agressão à dignidade daquele a quem se dirige, através da qual se expressa uma ausência de consideração ou reconhecimento para com esta. 
Luis Roberto Cardoso de Oliveira, inspirado no ensaio clássico de Marcel Mauss (2003) sobre "reciprocidade", sugere que a noção de "consideração" poderia ser comparada à categoria maori do hau: cada sujeito tem obrigação de tratar os outros com consideração ("dar" consideração), de aceitar a consideração alheia, e de retribuí-la. Negar esse "reconhecimento" do outro ameaça a manutenção do vínculo social, e enseja um tipo de resposta emocional que Cardoso de Oliveira busca circunscrever por meio da noção de "ressentimento". ${ }^{5}$ Reivindicações por reconhecimento são fenômenos dificilmente codificáveis na linguagem do direito positivo, pois não podem ser satisfeitas pela mera obediência a regras: exigem a transmissão de sinais de apreço pelo outro.

Em um contexto em que um sujeito social reivindica algum tipo de "reconhecimento", atos e gestos do outro podem ser interpretados como sinais de indiferença que o inferiorizam, rebaixam seu status, e podem ser sentidos como agressões à sua dignidade. Acompanhando essa linha de argumentação, expressar vergonha de alguém - de algo que esta pessoa "faz" ou algo que esta pessoa "é" - não poderia ser considerado um gesto ofensivo pela própria pessoa?

5 O "ressentimento" aparece como tema relativamente frequente em uma literatura que abordou conflitos e processos macropolíticos sob perspectiva histórica (Elias, 1997; Ferro, 2009; Haroche, 2001). O "ressentimento" tende a ser retratado, nesses trabalhos, como disposição emocional que se instala entre membros de grupos subalternos em contextos em que essa subalternização seja vista (ou passe, em um dado momento, a ser percebida) como ilegítima; ou em situações em que pretensões de superioridade reivindicadas por um grupo não são plenamente reconhecidas por outros. A ausência de reconhecimento se faria acompanhar da construção coletiva de sentimentos de humilhação e ofensa, e ações voltadas à reparação dessa situação. Essas disposições afetivas possuem um potencial para servir como poderosos motivadores para a ação, podendo assumir desde formas explosivas de ação contra aquele que provocou o ressentimento (incluindo atos de agressão física, violência letal, guerras) até a forma daquilo que o historiador Marc Ferro (2009, p. 169), inspirado em Nietzsche, chamou de "o ressentimento dos colonizados": uma "vingança imaginária" que o homem do ressentimento "rumina", em face da impossibilidade da ação. Em muitos desses trabalhos o "ressentimento" tende a ser retratado sob uma perspectiva bastante negativa, por ser associado a emoções virtualmente explosivas com um potencial para a desumanização do agente visto como provocador do ressentimento e para a disrupção dos próprios vínculos sociais - ainda que este possa aparecer também sob uma ótica menos desabonadora, a partir de uma perspectiva igualitarista, enquanto uma energia que mobiliza a insurgência dos subalternos contra situações que passam a ser percebidas como intoleráveis. Em todos esses casos, essa categoria remete a intensas motivações para a ação, subjacentes a conflitos entre grupos e categorias de pessoas. 
A cena de conflito familiar narrada por Karine expressa sua sensibilidade àquilo que interpreta como um sentimento de "vergonha" expressado por sua mãe, e a vergonha da mãe ofende a filha. Sentir-se pessoalmente ofendida, nesse caso, evoca sentidos aproximáveis à noção de "mágoa", que Karine emprega em outros momentos de sua fala, por referência a seus sentimentos acerca de injúrias que sofrera na juventude perpetradas por colegas de escola. Karine, contudo, distingue e qualifica o sentimento que a mãe expressa nessa situação como uma forma "sutil" de agressão, manifesta através de uma linguagem das emoções. Mesmo na ausência da "injúria”, uso explicitamente agressivo da fala que demarca fronteiras entre categorias sociais, é possível rebaixar o outro expressando vergonha por aquilo que ele "é" ou "faz". A "vergonha" da mãe é sentida nesse contexto, pela filha, como uma forma pela qual é comunicado o status inferior da homossexualidade: a negação de uma forma de consideração pela qual a filha anseia.

\section{Considerações finais}

Independentemente do modo como a mãe de Karine tenha interpretado subjetivamente essa situação vivenciada por ambas, a filha identifica na atitude da mãe sinais convencionais de "vergonha". Sob essa lógica, exibir a homossexualidade de forma "desavergonhada" significaria expor-se à língua ferina dos vizinhos, incorrendo no risco de perda de prestígio para a jovem e para a família à qual ela pertence. Karine, contudo, opera de forma subversiva com esse mesmo código da "vergonha", embaralhando os termos que o constituem. Para ela, a homossexualidade não é (e não deveria ser) considerada motivo de "vergonha" - uma premissa que comparece integrada à visão de mundo igualitária cultivada pela jovem e a seu alinhamento político às agendas do movimento LGBT. A "vergonha" que a filha percebe em sua mãe, nesse contexto, é reconhecida como uma "ofensa"; em vez de endossar julgamentos morais que desqualificam a homossexualidade, a jovem (ao mostrar-se ofendida) questiona a hierarquia que os legitima.

Outro aspecto significativo para a compreensão do sentido desses discursos é que a queixa de Karine não é lançada diretamente à mãe, mas ao pesquisador que a interpela no contexto da entrevista. A entrevista é uma situação 
social que oferece um espaço privilegiado - ainda que não necessariamente o único - para a verbalização de sentimentos/ressentimentos associados a conflitos vivenciados na esfera familiar. A história de vida de Karine não é meramente narrada, mas narrada para alguém - nesse caso, para um antropólogo que foi reconhecido como uma pessoa que partilha certas afinidades políticas com sua interlocutora, preocupado com a desconstrução de preconceitos contra pessoas LGBT. Esse contexto certamente favoreceu a enunciação dos discursos emocionais apresentados acima, e pode (de uma maneira ou de outra) ter comparecido no modo como a mãe de Karine é construída como pessoa-personagem significativa em seu depoimento. A análise desse caso mostra como categorias emocionais podem comparecer não somente na demarcação e reforço de hierarquias, mas também em sua contestação, evidenciando a capacidade dos sujeitos de exercer formas de agência e criatividade a partir de um leque de alternativas oferecidas no interior de linguagens culturais convencionais.

\section{Referências}

ABU-LUGHOD, L.; LUTZ, C. Introduction: emotion, discourse and the politics of everyday life. In: LUTZ, C.; ABU-LUGHOD, L. (ed.). Language and the politics of emotion. Cambridge: Cambridge University Press, 1990. p. 1-23.

AHMED, S. Shame before others. In: AHMED, S. The cultural politics of emotions. New York: Routledge, 2004. p. 101-121.

BARROS, M. L. de. A memória familiar. In: BARROS, M. L. de. Autoridade e afeto: avós, filhos e netos na família brasileira. Rio de Janeiro: Jorge Zahar, 1987. p. 73-104.

BATESON, G. Toward a Theory of Schizophrenia. In: BATESON, G. Steps to an ecology of mind. Chicago: The University of Chicago Press, 1972. p. 201-227.

BECKER, H. A história de vida e o mosaico científico. In: BECKER, H. Métodos de pesquisa em ciências sociais. São Paulo: Hucitec, 1999. p. 101-115.

BENEDICT, R. O crisântemo e a espada: padrões da cultura japonesa. São Paulo: Perspectiva, 1972.

BISPO, R. Tempos e silêncios em narrativas: etnografia da solidão e do envelhecimento nas margens do dizível. Etnográfica, v. 20, n. 2, p. 251-274, 2016. 
BUTLER, J. Bodies that matter: on the discursive limits of "sex". New York: Routledge, 1993.

CABRAL, J. de P.; LIMA, A. P. de. Como fazer uma história de família: um exercício de contextualização social. Etnográfica, v. 9, n. 2, p. 355-388, 2005.

CAMPBELL, C. A ética romântica e o espírito do consumismo moderno. Rio de Janeiro: Rocco, 2001.

COELHO, M. C. Narrativas da violência: a dimensão micropolítica das emoções. Mana, Rio de Janeiro, v. 16, n. 2, p. 265-285, 2010.

COURTINE, J.-J.; HAROCHE, C. Histoire du visage: exprimer et taire ses emotions, du XVI siècle au début du XIX siècle. Paris: Payot \& Rivages, 2007.

DEBERT, G. G. Problemas relativos à utilização da história de vida e história oral. In: CARDOSO, R. C. L. A aventura antropológica: teoria e pesquisa. Rio de Janeiro: Paz e Terra, 1986. p. 141-156.

DESPRET, V. As ciências da emoção estão impregnadas de política? Catherine Lutz e a questão do gênero das emoções. Fractal: Revista de Psicologia, v. 23, n. 1, p. 29-42, jan./abr. 2011.

DUARTE, L. F. D. O império dos sentidos: sensibilidade, sensualidade e sexualidade na cultura ocidental moderna. In: HEILBORN, M. L. A. (org.). Sexualidade: o olhar das ciências sociais. Rio de Janeiro: Jorge Zahar, 1999. p. 21-30.

DUARTE, L. F. D.; GOMES, E. de C. Três famílias: identidades e trajetórias transgeracionais nas classes populares. Rio de Janeiro: Editora FGV, 2008.

ELIAS, N. Os alemães: a luta pelo poder e a evolução dos habitus nos séculos XIX e XX. Rio de Janeiro: Jorge Zahar, 1997.

ERIBON, D. Reflexões sobre a questão gay. Rio de Janeiro: Companhia de Freud, 2008.

FACCHINI, R. Entre umas e outras: mulheres, (homo)sexualidade e diferenças na cidade de São Paulo. 2008. Tese (Doutorado em Ciências Sociais) - Instituto de Filosofia e Ciências Humanas, Universidade Estadual de Campinas, Campinas, 2008.

FERRO, M. O ressentimento na história. Rio de Janeiro: Agir, 2009.

FOUCAULT, M. História da sexualidade I: a vontade de saber. Rio de Janeiro: Graal, 1988.

FOUCAULT, M. Aula de 19 de fevereiro de 1975. In: FOUCAULT, M. Os anormais: curso no Collège de France (1974-1975). São Paulo: Martins Fontes, 2001. p. 211-254.

FOUCAULT, M. Sexualidade e solidão. In: BARROS DA MOTA, M. (org.). Ética, sexualidade e política. Rio de Janeiro: Forense Universitária, 2004. p. 92-103. 
GOFFMAN, E. Ritual de interação: ensaios sobre o comportamento face a face. Petrópolis: Vozes, 2012.

GONÇALVES, M. A. Etnobiografia: biografia e etnografia ou como se encontram pessoas e personagens. In: GONÇALVES, M. A.; CARDOSO, V.; MARQUES, R. (org.). Etnobiografia: subjetividade e etnografia. Rio de Janeiro: 7 Letras, 2012. p. 12-37.

HAROCHE, C. Elementos para uma teoria política do ressentimento: laços emocionais e processos políticos. In: BRESCIANI, S.; NAXARA, M. (org.). Memória e (res) sentimento: indagações sobre uma questão sensível. Campinas: Editora da Unicamp, 2001. p. 333-349.

HOCHSCHILD, A. R. Trabalho emocional, regras de sentimento e estrutura social. In: COELHO, M. C. (org.). Estudos sobre interação: textos escolhidos. Rio de Janeiro: EdUERJ, 2013. p. 169-209.

LUTZ, C. Unnatural emotions: everyday sentiments on a Micronesian atoll and their challenge to Western theory. Chicago: University of Chicago Press, 1988.

LUTZ, C.; WHITE, G. The anthropology of emotions. Annual Review of Anthropology, n. 15, p. 405-436, 1986.

MARCUS, G. Ethnography in/of the world system: the emergence of multi-sited ethnography. Annual Review of Anthropology, v. 24, p. 95-117, Oct. 1995.

MAUSS, M. A expressão obrigatória dos sentimentos. In: FIGUEIRA, S. (org.). Psicanálise e ciências sociais. Rio de Janeiro: Livraria Francisco Alves, 1980. p. 56-63.

MAUSS, M. Ensaio sobre a dádiva. In: MAUSS, M. Sociologia e antropologia. Rio de Janeiro: Cosac Naify, 2003. p. 183-314.

MILLER, W. I. Humiliation, and other essays on honor, social discomfort and violence. New York: Cornell University Press, 1993.

MILLER, W. I. The mystery of courage. Cambridge: Harvard University Press, 2000.

OLIVEIRA, L. Diversidade sexual, gênero e família: notas sobre o problema da superioridade moral da heterossexualidade. In: PASSAMANI, G. (org.). (Contra) pontos: ensaios de gênero, sexualidade e diversidade sexual. Campo Grande: Editora UFMS, 2011. p. 53-65.

OLIVEIRA, L. Os sentidos da aceitação: família e orientação sexual no Brasil contemporâneo. 2013. Tese (Doutorado em Antropologia Social) - Museu Nacional, Universidade Federal do Rio de Janeiro, Rio de Janeiro, 2013.

OLIVEIRA, L. R. C. Existe violência sem agressão moral?. Revista Brasileira de Ciências Sociais, v. 23, n.67, p. 135-146, 2008. 
PITT-RIVERS, J. Honra e posição social. In: PERISTIANY, J. G. Honra e vergonha: valores da sociedade mediterrânea. Lisboa: Fundação Calouste Gulbenkian, 1971. p. 11-59.

POLLAK, M. Os homossexuais e a AIDS: sociologia de uma epidemia. São Paulo: Estação Liberdade, 1990.

QUEIROZ, M. I. P. de. Relatos orais: do "indizível" ao "dizível". In: QUEIROZ, M. I. P. de. Variações sobre a técnica de gravador no registro da informação viva. São Paulo: T. A. Queiroz, 1991. p.1-26.

RADCLIFFE-BROWN, A. R. On joking relationships. Africa: Journal of the International African Institute, v. 13, n. 3, p. 195-210, July 1940.

RAMOS, E. As negociações no espaço doméstico: construir a "boa distância" entre pais e jovens adultos coabitantes. In: BARROS, M. L. de. Família e gerações. Rio de Janeiro: Editora FGV, 2006. p. 39-65.

REZENDE, C. B.; COELHO, M. C. Antropologia das emoções. Rio de Janeiro: Editora FGV, 2010.

SEDGWICK, E. K. A epistemologia do armário. Cadernos Pagu, n. 28, p. 19-54, jan./jun. 2007.

STRAUSS, A. L. Espelhos e máscaras: a busca da identidade. São Paulo: Edusp, 1999.

THOMAS, W. I. The unadjusted girl: with cases and standpoint for behavior analysis. Boston: Little, Brown, and Company, 1923.

Recebido: 31/05/2018 Aceito: 05/02/2019 | Received:5/31/2018 Accepted: 2/5/2019 